\title{
Production Networks and Unbundling: Reformulating the Conceptual Framework in Theory, Empirics, and Policy Discussion
}

\author{
Fukunari Kimura \\ Chief Economist \\ Economic Research Institute for ASEAN and East Asia (ERIA) \\ Tokyo, Japan
}

\begin{abstract}
This paper employs the concept of "unbundling" proposed by Baldwin (2016) and provides an overview of the dynamic transformation of the pattern of international division of labor in East Asia from the viewpoint of theory, empirics, and policy discussion. East Asia has led the world in aggressively utilizing the second unbundling, or the mechanics of international production networks centered by machinery industries. Yet there is still ample room for expanding and deepening the involvement in such a pattern of international division of labor. At the same time, a wave of digital technology has arrived in East Asia, and the application of new information and communication technology (ICT) and the third unbundling have become important policy agenda items. This paper concisely presents the conceptual framework of "unbundling," particularly the second and the third, and discusses a number of issues on empirical studies and policy discussion over development strategies and required sets of policies.
\end{abstract}

Keywords - international division of labor, connectivity, digital economy, information and communication technology (ICT), development strategies

\section{EAST ASIA AS A PIONEER}

East Asia, including Northeast Asia and Southeast Asia, has led the world in extending production networks centered by machinery industries. Countries that are successful in aggressively utilizing the mechanics of production processwise or task-wise international division of labor or the second unbundling, have been limited to East Asian countries, some Eastern European countries, Mexico, and Costa Rica. Furthermore, only some East Asian countries have reached the stage of formulating industrial agglomeration together with the fragmentation of production. The spectacular economic growth in East Asian countries since the latter half of the 1980s is derived from the effective use of the second unbundling. Once international production networks have been established, they have sometimes worked as a supply or demand shock transmission mechanism at the event of financial crises or natural disasters. At the same time, these networks have shown their robustness against supply or demand shocks. Manufacturing-based economic development has generated a massive amount of employment for relatively poor people, and rapid poverty alleviation has been achieved with internal labor movements.
It perhaps was not well planned at the beginning. However, looking back at the past three decades, development strategies applied by developing countries in East Asia can be interpreted as consistent with the effective use of the second unbundling. In the latter half of the 1980s and the 1990s, countries in the region started inviting foreign direct investment (FDI) aggressively, and international production networks in the electric and electronic industries were established. After the Asian Currency Crisis, China emerged with a strong pace of industrialization, and in response ASEAN wiped out its old import-substitution industrialization strategy from its scheme of regional integration. However, there exist huge gaps in the degree of participation in international production networks across countries or regions within East Asia. There is still ample room for widening and deepening the involvement in the second unbundling.

On the other hand, a wave of digital technology has arrived in East Asia and started changing people's daily lives. Advanced communication technology has made matching much easier not only for business-to-business (B2B) transactions but also for business-to-consumer (B2C) and consumer-to-consumer (C2C) transactions. Consequentially, new business models have mushroomed in various industries, including wholesale and retail, transportation, tourism and travel, and others. In the near future, in terms of production processes and tasks, we will step beyond the second unbundling and into the world of the third unbundling, in which remotely located individuals take care of one task together. Policymakers in the region are facing challenges in understanding the implication of the new digital economy and incorporating it into their development strategies.

Japan and Japanese companies have played an important role in the development of the second unbundling in East Asia. Japanese companies have taken strong initiatives for extending international production networks and forming industrial agglomerations. The Official Development Assistance (ODA) and Other Official Fund (OOF) programs by the Japanese Government have also contributed to the development of necessary infrastructure. Furthermore, Japan's economic integration strategy in the past two decades has strengthened the region's interest in international production networks. By now, Japan has gained confidence in how to widen and deepen involvement in the second unbundling. However, can Japan and Japanese 
companies take a leadership role in the digital economy and the approaching third unbundling? This is what Japanese must seriously consider. This paper explains the unbundling concept up to the third unbundling, reinterprets production networks in East Asia, and extends discussion for new development strategies and necessary policy packages.

\section{THE CONCEPT OF UNBUNDLING}

\section{A. Three Levels of Unbundling}

The concept of unbundling can be illustrated as in Figure 1. Unbundling is derived from overcoming a geographical distance with technological breakthroughs. In the first half of the $19^{\text {th }}$ century, the transportation revolution occurred, facilitated by steam ships and railroads, and the unbundling of production and consumption across national borders was made possible. This led to the industry-wise international division of labor and international trade in raw materials and finished products. Around 1990, the ICT revolution made the movement of ideas easier, production began to be fragmented, and the task-wise international division of labor started. Parts and components dominated international trade; technology in developed countries and labor in developing countries were connected. Presently, further ICT innovation has reduced face-to-face costs, leading to an imminent third unbundling in which tasks are fragmented into smaller components carried out by remotely located individuals.
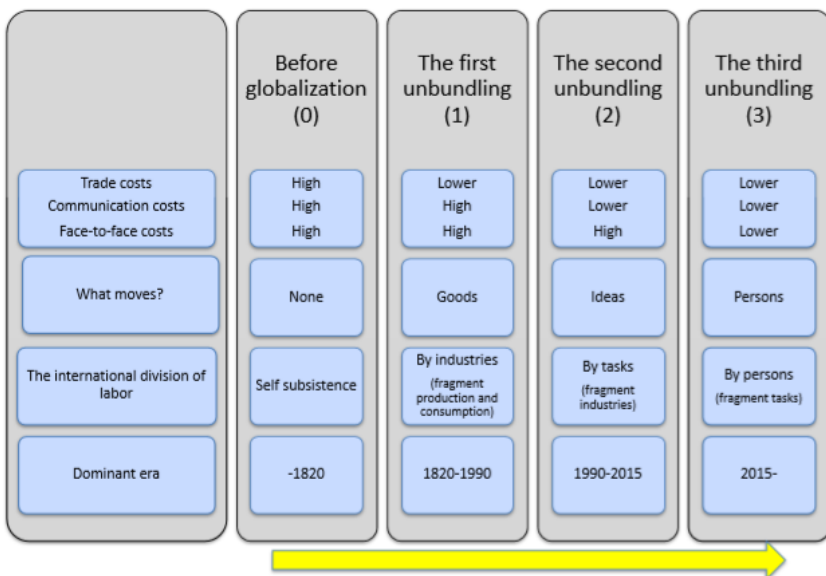

Source: the Author

Fig. 1. Overcoming Distance and Unbundling á la Baldwin

The level of unbundling utilized depends on the technological nature of the industry as well as corporate strategies. Thus, in the real world multiple levels of unbundling simultaneously exist within a country or region. However, the maximum level of unbundling that can occur in a region is constrained by geographical conditions, hard infrastructure, human resources, the economic system and policy environment, and more. In development strategies, each country's government may want to expand the scope of unbundling for corporate activities.

\section{B. The Conceptual Framework for the Second Unbundling}

Studies on international production networks and related global value chains had already been accumulated when Baldwin proposed the concept of the second unbundling. The following is a short list of theoretical approaches on this issue.
The first is the fragmentation theory (Jones and Kierzkowski (1990)). If we interpret this theory in the current context, it actually describes an economic logic on special characteristics of the second unbundling at the task level vis-à-vis the first unbundling at the industry level.

Figure 2 illustrates fragmentation of production. For example, consider a production plant in the electronics industry. Before fragmentation, such an industry is capital or human capital-intensive, and the production plant is located in a capital or human capital-abundant developed country. However, if we look at production processes from upstream to downstream, we may find that the plant consists of various tasks with different technologies and diversified factor inputs. Thus, if we can fragment the plant into several production blocks and locate them in places with proper location advantages, we may save on the total production cost. This is fragmentation of production.

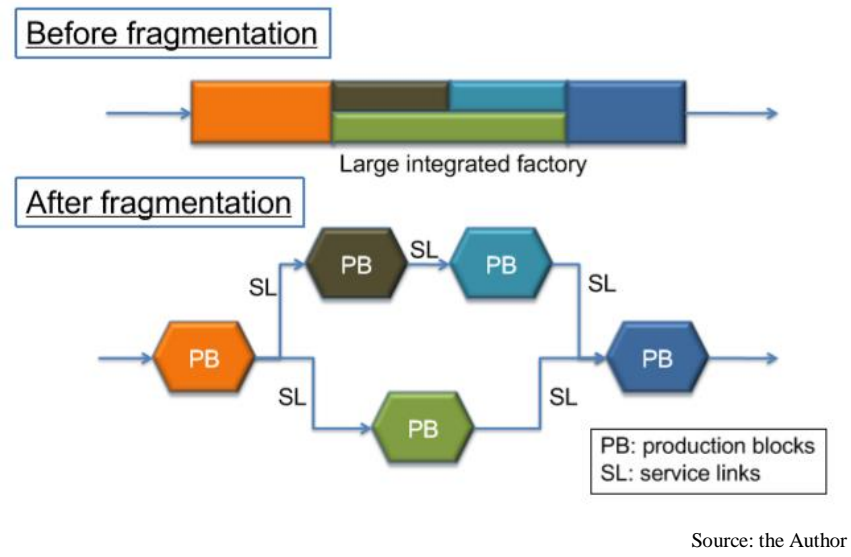

Fig. 2. The Fragmentation Theory

To make such fragmentation economically viable, two conditions must hold. First, differences in location advantages should reduce production costs in production blocks. The importance of location advantages is in parallel with the first unbundling, in which differences in the endowment of productive factors or differences in wages are exploited. However, in the second unbundling, a firm can control the whole supply chain and bring the production technology and managerial know-how into developing countries. Furthermore, each firm can cut out production blocks as it likes. These elements are different from the case of industry-wise international division of labor. Second, service link costs to connect remotely located production blocks must not be too high. Some additional costs are inevitable because fragmentation of production necessarily requires the transportation of parts and components as well as the coordination of production among production blocks. However, such costs should be low. Otherwise, fragmentation is not chosen by a firm.

Location advantages and service link costs are important criteria not only for an industry's or a firm's decision to pursue fragmentation of production, but also for developing countries to consider what is needed to participate in production networks. Location advantages include the supply of inexpensive labor as well as the procurement of infrastructure services, such as industrial estates, electricity supply, and others. On the other hand, the reduction in service link costs is derived from trade liberalization and 
facilitation, the development of logistics infrastructure, and the liberalization of logistics services. In East Asian countries that have been successful in utilization of the second unbundling, these two conditions have been fundamentally met.

The second conceptual framework is two-dimensional fragmentation (Kimura and Ando (2005)). It claims that fragmentation of production is a combination of fragmentation in two dimensions: the dimension of geographical distance and the dimension of corporate control, i.e., within a firm or between firms. And, in the later dimension, particularly in cases of inter-firm transactions with small and medium enterprises (SMEs) or local firms in developing countries in one end of transactions, transactions are almost for sure in a short geographical distance in order to save transaction costs. This mechanism explains well what has been observed in East Asia: industrial agglomeration has formed with inter-firm transactions at the core, and the fragmentation of production and the formation of industrial agglomeration have proceeded simultaneously. In fact, a firm in a production network typically combines short and long-distance transactions, considering widelydefined transportation costs with time costs and the relationship with business counterparts (Kimura (2010)). A short-distance transaction tends to be chosen when a network set-up cost is small, service link costs are high, and the importance of location advantages is low. Furthermore, a short-distance transaction is likely to be inter-firm and occur when the credibility of the business partner is low, the power balance with the business partner is asymmetric, and the interface between firms is the type of total integration. The opposite happens in cases of long-distance transactions.

Such a spatial structure of production networks suggests the importance of the formation of industrial agglomeration in development strategies, together with fragmentation of production. A country with a substantial population size must form an industrial agglomeration with domestic vertical links that generate a certain thickness of value added, rather than just having simplistic cross-border production sharing, such as Maquiladora in Mexico and export processing zones with $100 \%$ imports and $100 \%$ exports. Moreover, we know that most technology transfer and spillover from multinational to local firms comes along with a vertical division of labor within industrial agglomeration (Kimura, Machikita, and Ueki (2016)). Although the formation of industrial agglomeration requires massive infrastructure investment and appropriate policies, it would be an important step for effectively utilizing the second unbundling for economic development

The third framework is the concept of agglomeration and dispersion forces in spatial economics or new economic geography. ${ }^{1}$ In a spatial economic model, when the transport cost between a core and a periphery is reduced, two forces are generated: agglomeration forces with which the core attracts a wide range of economic activities and dispersion forces that move certain economic activities to the periphery. In a typical theoretical setting, equilibria in which agglomeration forces dominate are obtained. However, a certain level of dispersion forces is obtained when a negative agglomeration forces or congestion effects are

As for the structure of theoretical models in spatial economics, see Fujita, Krugman, and Venables (1999) and Baldwin, Forslid, Martin, Ottaviano, and Robert-Nicoud (2003). strong at the core or differences in development stages between the core and the periphery are so large that a huge disparity in wages and others exists. This suggests what a developing country should do in order to participate in international production networks. From the viewpoint of the periphery, a reduction in transport costs by trade liberalization/facilitation and the development of transportation infrastructure, by itself, may not help attract production blocks. In addition to a reduction in transport costs, policies to enhance location advantages are needed at the same time. Furthermore, in the real globalizing world, multiple goods and productive factors may move at the same time. In such a case, the spatial economic approach could be helpful.

The fourth is the concept of trade in value added (TiVA). ${ }^{2}$ TiVA disseminated the idea of decomposing each country's value added embodied in goods and services and actually measured it by utilizing international input-output tables. This enhanced our understanding on international production networks. In particular, its contribution is substantial for measuring domestic and foreign value added ratios in each country's production and exports and in calculating the upstreamness of each country's industries in global value chains.

However, we have to be careful in the limitation due to the data constraints embedded in international input-output tables. One issue is the data reliability of the detailed input structure. Another is that the data do not directly capture each value chain. Although the international input-output tables distinguish domestic and imported intermediate inputs, the output/export side is regarded as homogeneous for each industry. In addition, no information is provided for distinguishing the first and second unbundling; we do not know the speed or frequency of transactions, nor do we know whether transactions are relation-specific. Furthermore, a time-series comparison must be made with great care because each year's table is in the nominal prices. Moreover, domestic value added ratios tend to attract policymakers' interest. However, it is often dangerous to set such ratios as a policy target because they depend on not only the quality and quantity of domestic inputs but also other factors, such as the degree of participation in international production networks, the size of domestic economy, the existence of resourcebased exports, and others.

\section{Approach to the Third Unbundling}

From the viewpoint of newly developed and developing countries, the current abrupt technological progress has two faces: information technology (IT) and communication technology (CT). IT is represented by artificial intelligence (AI), robotics, and German Industry 4.0. IT provides explosively faster data processing and machine learning on repeated data and accelerates the substitution of humans by machines. Such efficiency enhancement tends to reduce the number of tasks and thus generate geographical concentration of economic activities. We will perhaps observe some "reshoring" of manufacturing activities back to developed countries. On the other hand, CT such as the Internet and smartphones reduces face-to-face costs and overcomes geographical distance. Matching costs in B2B,

Much earlier than the TiVA, Baldwin and Kimura (1998) proposed the method of capturing international trade in terms of embodied value added rather than the gross value. Furthermore, they tried to decompose activities into the one by multinationals and the other by local firms. 
$\mathrm{B} 2 \mathrm{C}$, and $\mathrm{C} 2 \mathrm{C}$ are reduced, which potentially encourages the division of labor and generates dispersion forces. The world is not "flat" yet. Since wage gaps across countries remain huge, the further usage of CT may accelerate the international division of labor. We still do not know whether concentration forces or dispersion forces will become dominant in the future. Perhaps the two forces will grow in parallel for a while amongst our deepening economic and social involvement in digital technology. Newly developed and developing countries must follow up the advancement of IT while aggressively utilizing CT to attract economic activities.

At the stage of the third unbundling, a reduction in face-toface costs allows us to unbundle a task into individuals across countries (Figure 3). Since no official statistics exists, it is difficult to quantify international transactions, and it is likely they are not yet huge. However, we have already observed similar kinds of division of labor within a country. With the improvement of internet connectivity, telecommuting will surely become more popular, and individual-based service outsourcing through the Internet will expand. In Japan, C2C service matching services can be found, such as Coconala. Across the world, job matching platforms such as Upwork, Witmart.com, and Amazon Mechanical Turk are becoming more prominent. Eventually, services that used to be internalized within a firm will be outsourced; small businesses and individuals will be able to participate in outsourcing markets. To develop cross-border division of labor, we certainly have to overcome a number of difficulties, such as differences in languages and culture, payments, and troubleshooting. However, considering differences in factor prices, particularly wages, we can expect such unbundling across national borders soon.

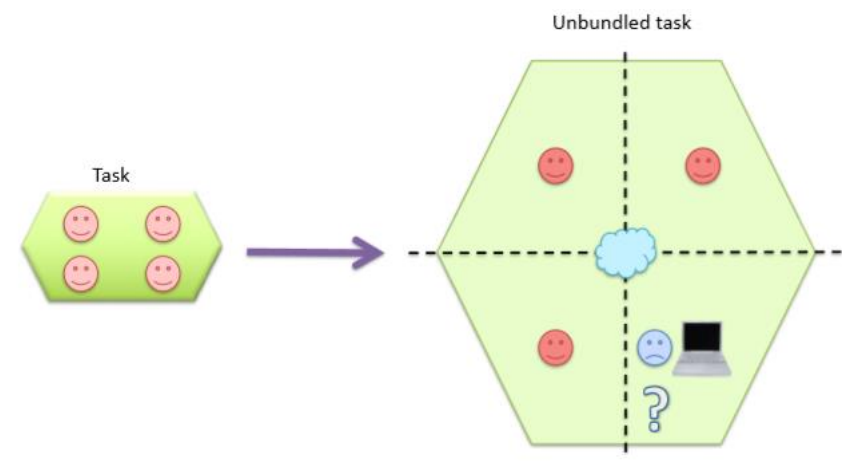

Source: the Author

\section{Fig. 3. The Third Unbundling}

Although it may take a few years to see substantial development of the third unbundling, we already observe the revitalization of existing industries based on the reduction in face-to-face costs. The CT usage in wholesale and retail, transportation services, tourism and lodging, and others has rapidly expanded in both developed and developing countries. For example, in retail trade, a sari-sari store at the corner of a village or a shopping mall at the fringe of a city used to be the place of matching where sellers display their goods and services there, buyers browse them, and then transactions occur (Figure 4). However, once an internet connection was established, matching costs in $\mathrm{B} 2 \mathrm{C}$ and $\mathrm{C} 2 \mathrm{C}$ transactions drastically come down with internet platforms. In such platforms, sellers' costs of displaying their goods and services are reduced, and buyers' costs of browsing them and negotiating prices also go down. Hence, various people, including small businesses and individuals, can participate in the market as a seller or a buyer. Competition is enhanced, but at the same time, the market expands. With a better internet environment in the near future, more goods and services will be traded on the Internet. The reduction in matching costs has already generated new businesses, including transportation services such as Uber, Grab, and Go-Jek, lodging services such as Airbnb, and other matching in sharing economies. E-payments are supporting such transactions, and various types of fintech have also mushroomed. These developments of new businesses will connect to the third unbundling.
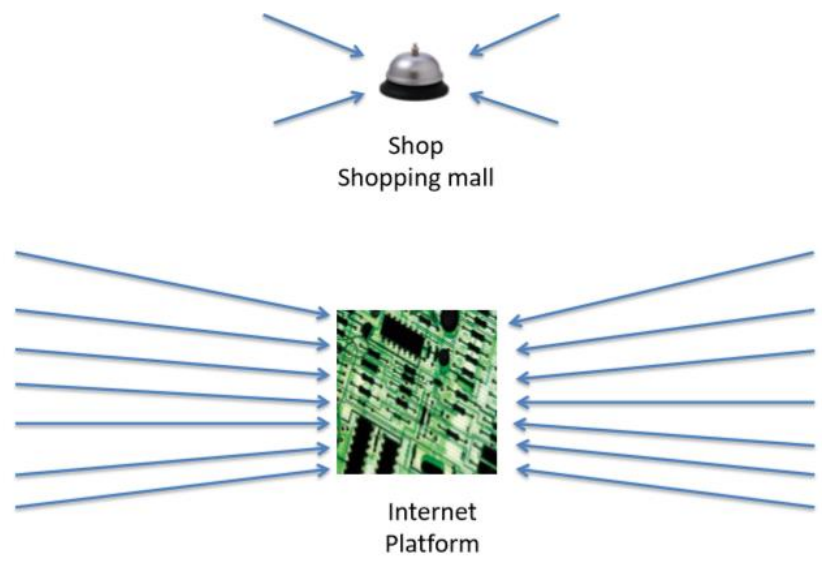

Source: the Author

Fig. 4. Reduction in Matching Costs and E-commerce

\section{EMPIRICAL EVIDENCES FOR UNBUNDLING}

In the first unbundling, activities of one industry or subsector are mostly conducted within a single country. Therefore, we could trace an entire process relatively easily using each country's production statistics and international trade data. However, for the second unbundling, it was not easy to statistically capture the whole picture, beyond cases of individual firms, because the system of primary statistics was not designed to describe this sort of division of labor. Particularly, even in the 1990s, only East Asia experienced a transition from simplistic cross-border production sharing to the extension of production "networks," which caused a delay in admitting the importance of international production networks. ${ }^{3}$ However, with the accumulation of research in the past 15 years, it is by now well recognized that international production/distribution networks, or the second unbundling, are an important form of international division of labor.

Since the other papers in this study group more or less discuss empirics of the second unbundling, this paper will not repeat the details. ${ }^{4}$ Instead, we would like to raise three points to investigate more in details. First, we observe a clear distinction between countries that participate in the second unbundling and those that do not, and the qualification depends on not only geographical and other

${ }^{3}$ The author began to work on international production/distribution networks in the latter half of the 1990s, and his research results were reported, for example, in Kimura (2001a, 2001b). However, his research started attracting the attention of academics only after Ando and Kimura (2005). The paper has been cited often.

${ }^{4}$ Obashi and Kimura (2016a) provide a literature survey of empirical studies on international production networks. 
natural conditions but also policy environment in a wider sense. We also see that the second unbundling has expanded and deepened over time, even within East Asia. ${ }^{5}$ It is therefore important to review and monitor the progress of the second unbundling. Second, more rigorous research is needed on the relationship between the sustained economic growth and rapid poverty alleviation achieved by East Asian countries. In other parts of the developing world, economic growth does not necessarily go together with poverty alleviation. How and why can East Asia do it? We believe that one of the key conditions is related to internal labor movements; we need further accumulation of empirical studies on this issue. 6 Third, "The Great Convergence" claimed by Baldwin (2016) must be verified more rigorously. Baldwin presents that the ratio of GDP between the Western developed country group and the developing country group expanded until the 1980s and shrunk after the 1990s. Additionally, he claims that such a sharp contrast between the two periods comes from a difference between the first and second unbundling. However, as for a list of countries in the developing country group, there is no problem in cases of China, Malaysia, and Thailand but India and Indonesia are also sometimes included. Since India and Indonesia are not yet fully engaged in the second unbundling, the story must be verified more rigorously.

At some point in the future, the quantification for the third unbundling must be conducted with the concept of mode 1 (cross-border) in services trade. However, so far, how to statistically capture such activities in domestic and cross-border statistics has not yet been established. Some data to evaluate the preparedness for the third unbundling are available, which includes the proportion of population with the Internet and smartphones, the ratio of participation in social media, and the utilization ratio of e-commerce, compiled from each country's industrial association data. ${ }^{7}$ However, the reliability of such data must be improved. In the near future, rigorous empirical studies may be conducted by utilizing big data provided by platform firms; however, the cost of accessing such data is so far too expensive for the average researcher. We must start out with defining the related statistical concepts and remodifying the statistical system.

\section{REFORMUlATING DEVELOPMENT STRATEGIES}

East Asia has largely been successful in its economic development by aggressively introducing the second unbundling into its development strategies. The central theme has been a "step-by-step" approach (Figure 5). Countries at the stage of "before globalization" (0) may go up to the stage of the first unbundling (1), and those reaching the first unbundling stage can proceed to the stage of the second unbundling (2). In this way, countries may step up one by one. This is the "step-by-step" approach. It is almost obvious that the former step provides good preparation for the next step, particularly for the preparedness in soft and hard infrastructure, human resource development, and proper economic system and policy environment.

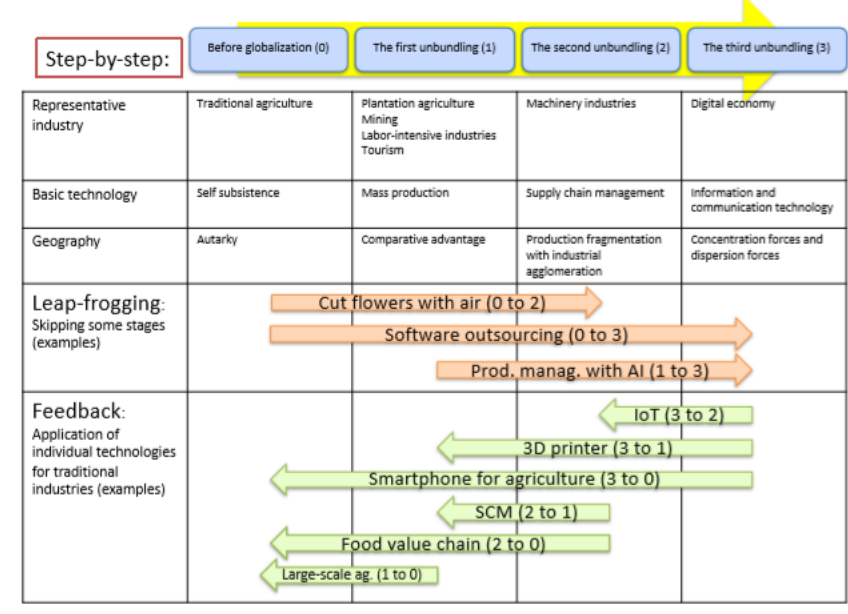

Source: the Author

Fig. 5. Unbundling and Industrial Development Strategies

This argument would hold to a certain extent in considering a step up from the second unbundling (2) to the third unbundling (3). For example, if a country has already developed a transportation system that can handle a just-intime system for the second unbundling, it can also provide the last-mile logistics for e-commerce. Managers and engineers who grew up with manufacturing and other related B2B services may also be useful for service outsourcing in the third unbundling. Moreover, the stable economy and society compatible with the second unbundling would also be suitable for the introduction of new business models. Development strategies in newly developed and developing countries in East Asia should certainly include such a "stepby-step" approach at the core.

However, the digital economy may provide other opportunities. We should not deny the possibility of leapfrogging, jumping up to software outsourcing, even if the second unbundling in machinery industries does not exist or a substantial industrialization in the first unbundling does not begin. Indeed, even in outer islands in Indonesia, digital connectivity has extended faster than physical connectivity. Although the potential of market expansion may be limited, it may be possible to skip some steps and jump-start the third unbundling. Such a leap-frogging scenario may need to be incorporated into development strategies.

Furthermore, the "feedback" application of new individual technologies for existing industries is currently ongoing. Although this application may not reformulate the fundamental nature of traditional industries, we have already observed the quantitative and qualitative improvement of production processes and value chains by introducing piecemeal advanced technologies and expanding markets with internet platforms. These are particularly effective in cases of individual technologies in the generation of the third unbundling. These elements should also be included in new development strategies. ${ }^{8}$

\footnotetext{
${ }^{5}$ See Ando and Kimura $(2013,2014)$ and Obashi and Kimura (2016b, 2017, 2018). 
TABLE I. UNBUNDLING AND REQUIRED POLICY ENVIRONMENT

\begin{tabular}{|c|c|c|c|c|}
\hline & $\begin{array}{c}\text { Before } \\
\text { globalization } \\
(0)\end{array}$ & $\begin{array}{l}\text { The first } \\
\text { unbundling (1) }\end{array}$ & The second unbundling (2) & The third unbundling (3) \\
\hline $\begin{array}{l}\text { International } \\
\text { commercial } \\
\text { policies and } \\
\text { behind-the- } \\
\text { border: } \\
\text { institutional } \\
\text { connectivity }\end{array}$ & & $\begin{array}{l}\text { Trade liberalization } \\
-\quad \text { Generalized } \\
\text { system of } \\
\text { preferences }\end{array}$ & $\begin{array}{l}\text { Trade liberalization and facilitation } \\
\text { - Free trade agreements } \\
\text { - Tariff removal } \\
\text { - TBT and e-customs } \\
\text { - Services (B2B) and investment } \\
\text { - Liberalization for GVCS }\end{array}$ & $\begin{array}{l}\text { Trade liberalization } \\
-\quad \text { Services: modes } 3 \text { and } 4 \text { (B2B, B2C, C2C) } \\
-\quad \text { (Cross-border) e-commerce, e-payments } \\
\text { - Free flow of data with supporting policies } \\
\text { Trade facilitation } \\
-\quad \text { SPS } \\
\text { - Standard and conformance } \\
\text { Supporting policies } \\
-\quad \text { Consumer protection, privacy protection } \\
-\quad \text { Competition policy } \\
-\quad \text { Taxation } \\
-\quad \text { Cybersecurity }\end{array}$ \\
\hline $\begin{array}{l}\text { Hard infrastructure } \\
\text { and location/living } \\
\text { environment: } \\
\text { physical } \\
\text { connectivity }\end{array}$ & & $\begin{array}{l}\text { Middle-grade } \\
\text { connectivity } \\
\text { - Roads } \\
\text { - Ports, airports } \\
\text { Infrastructure } \\
\text { services }\end{array}$ & $\begin{array}{l}\text { High-quality connectivity } \\
\text { - Large-scale ports } \\
\text { - Full-scale airports } \\
\text { - Multi-modal (cargos, passengers) } \\
\text { Urban and sub-urban development } \\
\text { for industrial agglomeration } \\
\text { - Logistics (highway system) } \\
\text { - Large-scale economic } \\
\quad \text { infrastructure services (industrial } \\
\quad \text { estates, electricity, energy, water) }\end{array}$ & $\begin{array}{l}\text { ICT connectivity } \\
-\quad \text { Internet connection } \\
\text { - Bridging connectivities } \\
\text { Urban development and urban amenities } \\
-\quad \text { Urban transport (LRT, subways, airport } \\
\text { access, access to resorts) } \\
\text { - Living environment (children's education, } \\
\text { medical services, safety in cities) } \\
\text { - Other urban amenities (possibilities of variety } \\
\text { of consumption) }\end{array}$ \\
\hline $\begin{array}{l}\text { Human aspects } \\
\text { and inclusiveness: } \\
\text { people-to-people } \\
\text { connectivity }\end{array}$ & $\begin{array}{l}\text { SME } \\
\text { development } \\
-\quad \text { E.g., cottage } \\
\text { industries }\end{array}$ & $\begin{array}{l}\text { SME development } \\
\text { - E.g., primary } \\
\text { exporters } \\
\text { Human resource } \\
\text { development } \\
\text { - Primary and } \\
\text { secondary } \\
\text { education }\end{array}$ & $\begin{array}{l}\text { SME development } \\
-\quad \text { E.g., supporting industry in } \\
\text { industrial agglomeration } \\
\text { Human resource development } \\
-\quad \text { Managers, engineers }\end{array}$ & $\begin{array}{l}\text { SME development } \\
\text { - E.g., ventures, start-ups } \\
\text { Consumer/people-centered policies } \\
\text { - Consumer protection } \\
\text { - Human resources for innovation and new } \\
\text { businesses } \\
\text { - Mobility of highly educated people } \\
\text { - Avoid digital divide } \\
\text { R\&D capability, innovation hubs }\end{array}$ \\
\hline
\end{tabular}

\section{UNBUNDLING AND THE SYSTEM OF REQUIRED POLICIES}

Unbundling is a concept on the form of international division of labor, and thus in the real world, different levels of unbundling naturally co-exist in a country or a region. However, the extent to which businesses can utilize higher levels of unbundling depends on geographical conditions, soft and hard infrastructure, human resources, economic institutions, and others. It is thus important to identify bottlenecks in order to make higher levels of unbundling available. Different levels of unbundling require qualitatively different policy environments. In general, higher levels of unbundling call for a more advanced policy package.

Table I is an attempt to construct a system of industrial promotion policies with different levels of unbundling. Here we apply the framework of connectivity used by ASEAN, which consists of institutional connectivity including international commercial policies and related domestic policies, physical connectivity taking care of hard infrastructure and location and residential environments, and people-to-people connectivity pertaining to human aspects and inclusiveness.

As for the institutional connectivity, while the first unbundling requires some trade liberalization, such as the generalized system of preferences (GSP) on primary products and textile products, the second unbundling must be supported by a wider scope of trade liberalization and facilitation, typically with comprehensive free trade agreements (FTAs). Furthermore, to step up from the second to the third unbundling, a policy environment supporting enhanced connectivity is essential, not only for B2B but also for B2C and C2C. In East Asian FTAs, service liberalization is always in delay. However, to activate the third unbundling, countries must proactively pursue liberalization and facilitation of services and investment. Moreover, benefits of consumers must be emphasized and a better digital environment has to be secured. Data flows should be basically free, regardless of domestic or cross-border, with a series of proper back-up policies including consumer protection, privacy protection, competition policy, taxation, cybersecurity, and other policies to take care of economic and social concerns. On this point, the e-commerce chapter in the Comprehensive and Progressive Agreement for TransPacific Partnership (CPTPP) is important in providing a basic direction to go.

Physical connectivity also requires a system of policies with different levels of unbundling. While the first unbundling simply needs medium-quality infrastructure, the second unbundling stands only with high-quality infrastructure that takes care of time costs and the reliability of logistics. Adequate transport and economic infrastructure to support efficient industrial agglomeration is also important. For the third unbundling, fast connection to the Internet is of course necessary. In addition, because the mobility of talented people across national borders will surely be activated, urban amenities to attract human resources for promoting innovation will become important (Gleaser, Kolko, and Saiz (2001)).

In the framework of people-to-people connectivity, we can include various items such as the promotion of small and medium enterprises (SMEs) and the development of human capital. Although the promotion of SMEs is often claimed to show the posture of emphasizing inclusiveness or equity in economic development, it is often unclear which sort of SMEs should be promoted. Before globalization, the attention would go mainly to cottage industries, for example. 
In the first unbundling, primary goods exporters may be important. In the second unbundling, supporting industry in industrial agglomeration becomes important. In the third unbundling, venture businesses and start-ups must be emphasized. Depending on the level of unbundling, the focus of SME promotion must differ.

The focus of human resource development must also differ across the different levels of unbundling. The first unbundling requires the propagation of elementary and secondary education, the second unbundling confronts the shortage of managers and engineers, and the third unbundling may generate demand for different types of human capital. Programmers and engineers are certainly in demand, and human resources with vigorous entrepreneurship are also necessary. We may need a drastic reformulation of our education and human capital development programs.

\section{CONCLUSION}

East Asia has the potential to remain a pioneer of the mechanics of unbundling. Moreover, there still exists room to further expand and deepen the second unbundling, and we must exploit such opportunities. At the same time, we should take advantage of the wave of digital technology and proceed towards the third unbundling by providing necessary policy environment. Japan must continuously apply a strategy to utilize the vigor of East Asian economies.

\section{ACKNOWLEDGMENT}

The author would like to thank Professor Shujiro Urata of Waseda University as well as participants in the meeting held on April 13, 2018 for helpful comments and suggestions. This paper is forthcoming in Public Policy Review.

\section{REFERENCES}

1] Ando, M. and F. Kimura (2005) "The Formation of International Production and Distribution Networks in East Asia", in T. Ito and A. K. Rose (eds.), International Trade in East Asia (NBER-East Asia Seminar on Economics, Volume 14), The University of Chicago Press, pp.177-213. The former version was distributed as NBER Working Paper No. 10167, National Bureau of Economic Research, Inc., December 2003

[2] Ando, M. and F. Kimura (2013) "Production Linkage of Asia and Europe via Central and Eastern Europe", Journal of Economic Integration, Vol.28 No.2, pp.204-240

[3] Ando, M. and F. Kimura (2014) "Evolution of Machinery Production Networks: Linkage of North America with East Asia", Asian Economic Papers, Vol.13 No.3, pp.121-163

[4] Baldwin, R. (2016) The Great Convergence: Information Technology and the New Globalization, Belknap Harvard University Press

[5] Baldwin, R., R. Forslid, P. Martin, G. Ottaviano, and F. RobertNicoud (2003) Economic Geography and Public Policy, Princeton University Press

[6] Baldwin, R. and F. Kimura (1998) "Measuring U.S. International Goods and Services Transactions", in R. E. Baldwin, R. E. Lipsey, and J. D. Richardson (eds.), Geography and Ownership as Bases for Economic Accounting, The University of Chicago Press: 9-36. The former version was distributed as NBER Working Paper No. 5516, National Bureau of Economic Research, Inc., March 1996. Reprinted in Bernard Hoekman, ed., The WTO and Trade in Services Volume I, Cheltenham: Edward Elgar, 2012, pp.187-214

[7] Fujita, M. P. Krugman, and A. J. Venables (1999) The Spatial Economy: Cities, Regions, and International Trade, MIT Press

[8] Glaeser, E.L. J. Kolko, and A. Saiz (2001) "Consumer City", Journal of Economic Geography, Vol.1 No.1, pp.27-50

[9] Jones, R. W. and H. Kierzkowski (1990) "The Role of Services in Production and International Trade: A Theoretical Framework", in R. W. Jones and A. O. Krueger (eds.), The Political Economy of International Trade: Essays in Honor of Robert E. Baldwin, Basil Blackwell, pp.31-48

[10] Kimura, F. (2001a) "Fragmentation, Internalization, and Interfirm Linkages: Evidence from the Micro Data of Japanese Manufacturing Firms", in L. K. Cheng and H. Kierzkowski (eds.), Global Production and Trade in East Asia, Kluwer Academic Publishers, pp.129-152

[11] Kimura, F. (2001b) "Intrafirm Fragmentation: Fujitsu, Ltd.'s Production of Hard Disk Drives", in L. K. Cheng and H. Kierzkowski (eds.), Global Production and Trade in East Asia, Kluwer Academic Publishers, pp.289-293

[12] Kimura, F. (2010) "The Spatial Structure of Production/Distribution Networks and the Implication for Technology Transfers and Spillovers", in D. Hiratsuka and Y. Uchida (eds.), Input Trade and Production Networks in East Asia, Edward Elgar, pp.158-180

[13] Kimura, F. (2018) “'Unbundlings' and Development Strategies in ASEAN: Old Issues and New Challenges", The Journal of Southeast Asian Economies, Vol. 35, No. 1, pp.15-23

[14] Kimura, F. and M. Ando (2005) "Two-dimensional Fragmentation in East Asia: Conceptual Framework and Empirics", International Review of Economics and Finance (special issue on "Outsourcing and Fragmentation: Blessing or Threat" edited by Henryk Kierzkowski), Vol.14, Issue 3, pp.317-348

[15] Kimura, F. and M. S. Chang (2017) "Industrialization and Poverty Reduction in East Asia: Internal Labor Movements Matter", Journal of Asian Economics, Vol.48, pp.23-47

[16] Kimura, F., T. Machikita, and Y. Ueki (2016) "Technology Transfer in ASEAN Countries: Some Evidence from Buyer-Provided Training Network Data", Economic Change and Restructuring, Vol.49 No.2, pp.195-219 Obashi, A. and F. Kimura (2016a) "Production Networks in East Asia: What We Know So Far", in G. Wignaraja (ed.), Production Networks and Enterprises in East Asia: Industry and Firm-Level Analysis, Asian Development Bank Institute and Springer: 33-64. The older version is in ADBI Working Paper Series No. 320, November 2011

[17] Obashi, A. and F. Kimura (2016b) "The Role of China, Japan, and Korea in Machinery Production Networks", International Economic Journal, Vol.33 No.2, pp.169-190

[18] Obashi, A. and F. Kimura (2017) "Deepening and Widening of Production Networks in ASEAN", Asian Economic Papers, Vol.16 No. 1, pp.1-27

[19] Obashi, A. and F. Kimura (2018) "Are Production Networks Passé in East Asia? Not Yet", Forthcoming in Asian Economic Papers.

[20] We Are Social (2018) Digital in 2018 in Southeast Asia $<$ https://digitalreport.wearesocial.com/> 